\title{
The logic of ideas in Christopher Hill's English revolution
}

Article

Accepted Version

Foxley, R. (2015) The logic of ideas in Christopher Hill's English revolution. Prose Studies: History, Theory, Criticism, 36 (3). pp. 199-208. ISSN 0144-0357 doi:

https://doi.org/10.1080/01440357.2014.994727 Available at https://centaur.reading.ac.uk/40350/

It is advisable to refer to the publisher's version if you intend to cite from the work. See Guidance on citing.

Published version at: http://dx.doi.org/10.1080/01440357.2014.994727

To link to this article DOI: http://dx.doi.org/10.1080/01440357.2014.994727

Publisher: Routledge

All outputs in CentAUR are protected by Intellectual Property Rights law, including copyright law. Copyright and IPR is retained by the creators or other copyright holders. Terms and conditions for use of this material are defined in the End User Agreement.

\section{www.reading.ac.uk/centaur}

\section{CentAUR}

Central Archive at the University of Reading

Reading's research outputs online 
Rachel Foxley

The logic of ideas in Christopher Hill's English revolution

Christopher Hill placed an epigraph from John Warr's The Corruption and Deficiency of the Laws of England (1649) at the start of Part II of Milton and the English Revolution. As Warr impressively declared, "The minds of men are the great wheels of things; thence come changes and alterations in the world; teeming freedom exerts and puts forth itself" (Hill, Milton 67). Hill was attracted to Warr's notion of "teeming freedom", his title for this part of his book, covering the early 1640s and the "radical underground"; with his characteristic eye for a telling quotation and ability to glean snatches of text which resonated with each other, he started one chapter of this section with Milton's similar "womb of teeming truth". But how far did Hill himself believe, with Warr, that the "minds of men are the great wheels of things"; how far did he trace "changes and alterations in the world" to what people thought? How did he understand the place of ideas in the minds of individuals and in the developing culture of a historical society?

The World Turned Upside Down took as its subject (and subtitle) "radical ideas", and painted an expansive picture of the "glorious flux and intellectual excitement" of the middle years of the English Revolution (14). Hill had already devoted a book to the intellectual origins of the revolution, and was to devote further works to the impact on ideas of the revolution and its failure, and to the intellectual career of John Milton in its revolutionary context. His works on the understanding of Antichrist and the interpretation of the Bible in seventeenth-century England were also contributions to an intellectual history which was one facet of a more fully cultural, social, and economic interpretation of the "century of revolution". Hill aspired to a "total history", and felt that the English revolution would only be understood by considering "the total activity of society". In Harvey Kaye's sympathetic 
assessment, "What Hill did develop is a social interpretation of the English Revolution which is not simply political, economic or religious, but rather comprehensive of all these.” Kaye sums up a part of Hill's achievement by citing Hobsbawm's account of the impact of Hill on British Marxist historiography: Hill had ensured that the "social history of ideas" formed a key part of that tradition $(107,129)$.

Hill tended to avoid the methodological and theoretical controversies which his colleague EP Thompson plunged into, but his historical focus and methods could be seen as similarly divergent from an austere model of Marxist historical materialism. He readily brushed away such charges, pointing out that "Marx himself did not fall into the error of thinking that men's ideas were merely a pale reflection of their economic needs, with no history of their own" (Intellectual Origins 3). The increasingly accommodating flexibility of Hill's “comparatively unsophisticated but expansive Marxist framework” (MacLachlan 180) was no doubt partly a matter of temperament: Hill cheerfully pointed to the "banal" nature of his conclusion in The Intellectual Origins of the English Revolution that "history is all very mixed up" (299). But it also evolved as part of a distinctive tradition of cultural "history from below" developed by other British Marxists. The formation of the New Left after the departure of Hill and others from the Communist Party of Great Britain in the wake of the Hungarian uprising (in 1957, in Hill's case) enabled this historiography to flourish, in spite of critical voices within this broader movement. Hill's experience of the CPGB may also, as MacLachlan suggests, have spurred him towards his explorations of the more anarchic forms of dissent at the further fringes of the revolution (180). Yet the messy profusion of ideas which Hill explored in The World Turned Upside Down still needed to be interpreted as part of an event which in some ways fitted the paradigm of a bourgeois revolution, although this was understood in less rigid ways in Hill's later work. Ideas did have a "history of their own”, but that history could not stand alone. 
The role of ideas in historical change is naturally a complex and contested issue within Marxist thought, bound up with questions of how the relationship between "base" and "superstructure" is to be understood, of individual agency and its relationship to larger historical processes, and of the nature of "ideology". Hill, in his occasional defences and discussions of his approach to the history of ideas, was keen to argue that they played a genuinely causal role in historical events: they were not the steam engine or the track it ran on, but they might be the "steam" which propelled it along that track (Intellectual Origins 2). Hill was insistent that ideas did play a fundamental role in the revolutionary events of the mid-seventeenth century, primarily because ideas were crucial to revolutionary motivation: "Most men have to believe quite strongly in some ideal before they will kill or be killed" (Intellectual Origins 1). For this reason, it would be impossible to construct a total and adequate account of the English Revolution which did not consider its ideas, and in many ways Hill's project was to supply the intellectual account which went along with and formed the more conscious aspect of the economic account.

Of course motivating people to fight might look rather more like the role of a manipulative ideology (at least in a bourgeois revolution) than of a generative set of ideas which might serve to bring people closer to a genuine (and potentially revolutionary) understanding of society. Much of Hill's work did, of course, examine the culture and ideologies of the "second culture" of bourgeois incipient capitalism which he linked to puritanism, an obvious motivator for civil war parliamentarians (Intellectual Origins 6). But in much of his work, and especially in The World Turned Upside Down, the ideas he was exploring were more ragged, inventive, and radical; ideas which he explored with such enthusiasm presumably because he found them attractive. Their genesis and role might require more complex explanations, especially since these radical ideas often had intrinsic connections with the puritan ideas espoused by the more conservative revolutionaries. The 
"teeming freedom" and "glorious flux" of these radical ideas might seem more various and more individual - indeed, recovering some of these ideas involved redeeming figures who were seen as on the fringes of sanity. Consequently these ideas might seem to offer more of a place for the agency of individual thinkers - however fruitless their efforts were at this particular historical juncture.

As we have seen, Hill somewhat defensively granted ideas a "history of their own", freeing them from economic determinism. At various points within his writings, he spent some energy elaborating on this issue, perhaps betraying some discomfort at the difficulty of locking the intellectual and economic stories neatly together. A key impulse was to grant ideas some autonomy: when he remarked that "Ideas do not advance merely by their own logic", he was conceding that ideas had their own logic, as they had their own history (Intellectual Origins 3). What Hill meant by this "logic" is difficult to tease out, but it always implied the potential for a specific development over time. At times it seems to be an intrinsic and intellectual logic that is expected to unfold: the notion of the priesthood of all believers carried within it further intellectual implications, of equality and of individualism.

Understood in this way, ideas were perhaps able to liberate their thinkers from the constraints of current conditions; or, to put it the other way round, people who conceived these potent ideas were able to exercise real agency which in due course might bring about historical change.

Appealing though this notion of intellectual agency might be, and appropriate though it might seem for the Christopher Hill who celebrated the defiantly marginal heroes of The World Turned Upside Down, the "logic" of ideas discerned by Hill more often operated quite differently. The inner logic of ideas was always propulsive, and rather than liberating ideas from the tyranny of economic determinism, it often seemed to liberate them instead from their inadequate or blinkered thinkers, enabling the ideas themselves to take their proper 
place in the forward march of economic and social formations. Hill famously argued that radical plebeian ideas ran in an underground stream "from Lollards to Levellers" ("From Lollards" 49-67). But those ideas seem to be more than the creation of those who thought them, and those who thought them seem to have done so in a partial and incomplete way. Thus the "third culture" which is the fundamental subject of The World Turned Upside Down and the context for Hill's Milton was confused and inchoate, but contained "what in the free discussion of the sixteen-forties were to emerge as serious and coherent rational ideas." These ideas were, perhaps, there in embryo before, but they were "mixed up" with ideas which did not have a forward-looking logic: "popular magic and belief in direct divine intervention" (Hill, Milton 78). This contamination of the coherent and rational by the backward and irrational was something which could evidently be detected by historians; but it would also tend to be winnowed out by the processes of history, as happened in Hill's view in the 1640s. In this process of clarification and purification of ideas, several forces seem to coalesce: a rather Enlightenment-inflected simple rationality; the pull exerted by social and economic developments on the ideas of different groups within society; and the contribution of systematizing "intellectuals".

Ideas, for Hill, aspired to rational, complete expression, and that rationality and coherence appear to be intrinsic. However, in the English revolution, ideas were not all pushed towards an objective truth; rather, they were sifted into "bodies of ideas" or even "blocks of ideas", which when boiled down to their "ultimate logic" proved to be antagonistic - describable indeed as "ideological position[s]". But Hill conceded: "Ideas are not, however, a reflex of economics" (Milton 69, 77). The concessive "however" is revealing: the "ultimate logic" shaping these blocks of ideas was surely economic; the "ideological positions" were those associated with the interests of conflicting socio-economic groups. In the contest between different sets of ideas, the one which flourished would be the one which served some 
purpose to people and hence "took on"; and this was socially determined, happening only if "it meets the needs of significant groups in the society in which it comes into prominence" (Intellectual Origins 3). Sets of ideas, or particular interpretations of a set of ideas, such as the Norman Yoke, became significant and distinguishable through their relationship to a social class or group. Hill thus felt able to look past the muddle of personal, individual beliefs to broader patterns of belief, and to classify them essentially into three "bodies of ideas" or three "cultures": that of the old ruling class, that of the rising bourgeois interest, and the plebeian "third culture". The broad outlines of a body of ideas might be determined by the inner logic of those ideas and their natural implications; these would then be cemented into social place by their economic implications, and interpreted in the light of the interests of the group who had latched onto them.

While these "bodies of ideas" could be delineated and distinguished both by looking at their content and by correlating it with social groups, the thinkers of these ideas could not themselves be relied on to make these distinctions clearly:

Once a body of ideas is in existence, individuals can take up some or all of it for the most diverse and personal reasons. But the fact that individuals hedge, fudge, are inconsistent, seek a quiet life, does not preclude the possibility of differentiating between the bodies of ideas with which they muddle. (Milton 77) What was more, in spite of Hill's emphasis on the plebeian origins of the "third culture", he gave "intellectuals" a key role in developing and disseminating the ideas; plebeian intellectuals existed but might have had little incentive to promote these ideas in the repressive years before the revolution. Thus "Before 1640 authentic expressions of wellthought-out ideas of the third culture are hard to come by." (That "authentic" is tantalizing, but it is not quite clear from the context whether "authentic" means articulated by the plebeians whose social and economic interests were genuinely expressed by these ideas.) 
Revealingly, Hill compares the English situation to nineteenth-century Russia, where socialist and Marxist intellectuals "imposed order and coherence on ideas that had long circulated among the peasantry and working class." There is a strange dialogue between the spontaneous plebeian generation of the ideas of this third culture, and the idea that coherence has to be "imposed" on them by intellectuals who, even if plebeian in origin, are slightly removed from that original matrix simply by being intellectuals (Milton 78). Again, the inherent potential of ideas escapes their original thinkers, and historical processes, including the appearance of these "intellectual" midwives at a propitious historical moment, guides the ideas towards their full realization.

Hill's thinking on the logic of ideas was manifested in his ambivalent treatment of the more mainstream radicals of the English revolution - the Levellers and Harringtonian republicans. I think it is clear that for all Hill's determination to allot thinkers either to the second (bourgeois) or third (plebeian) culture, and his enthusiasm for this plebeian radicalism, aspects of the "second" culture attracted him, and that this was partly because he saw certain ideas as a bridge between the two, opening up the possibility of moving from puritanism and capitalism towards a radical democracy (Kaye 112-4, 118). Individualism was one aspect of this: "Economic individualism in society (the breakdown of village community and gild, the rise of capitalism) combined with individualism in religion to produce a quite new authority, that contained within each man's breast" (Hill, Century 78). Clearly this new formation was at the heart of the rising bourgeois values according to Hill, and was one of the forces which enabled the bourgeoisie, once the revolution had started, to seize the moment and consolidate their political and economic power. C.B. Macpherson put a seventeenthcentury notion of "possessive individualism" at the start of the liberal tradition, and saw its possessive quality as the root of the subsequent problems of liberal democracy. Even he, however, also noted that seventeenth-century individualism came in different forms: an 
amoral Hobbesianism was rather different from a puritan emphasis on "the equal moral worth of every human being" (2). Hill followed Macpherson in his assessment of the exclusiveness and property-based nature of the Leveller franchise, and it may be assumed that he did not approve of the economic individualism which he analysed in the rising gentry and middle classes. But Hill's attraction to the other side of individualism, the empowering authority of individual conscience, is equally clear. He was clearly excited by the appearance of "this reliance on one 's own senses, one's own conscience, even against traditional authority" (Intellectual Origins 296). The failed, radical revolution of the 1640s and 1650s was enabled and inspired by the same conscientious individualism which in other forms and with other associations enabled the ultimately repressive bourgeois revolution to succeed. But one senses that, in Hill's view, no matter how much a certain type of individualism "took on" among early capitalists, the underlying logic of the individualist idea would and should ultimately carry people towards more radical and democratic conclusions.

Hill's account of the Levellers was profoundly shaped by a similar dynamic. When he assigned them to one block of ideas - as he apparently felt obliged to do - he placed them within the bourgeois revolution which succeeded. Aware that to others they might seem to deserve a place among the radicals of The World Turned Upside Down, he conceded "to restore the balance" that we should see them as "a very radical left wing of the revolutionary party", who also - unlike some other characters in the book - had the virtues of principle and intellectual consistency, and were not fundamentally backward-looking. He accepted that the grandees' revolution hollowed out the republican measures which the Levellers advocated, robbing them of their democratic character (although he saw Leveller democracy as limited), but saw Lilburne as differing from the grandees "only in degree"; and indeed, saw the Levellers' acceptance of private property as grounding not only the potential alliance with the 
grandees but also their royalist flirtations in the 1650s (World 121-123). Because of their endorsement of property, even their republicanism was not robust.

This fundamental judgement about where the Levellers belonged - in combination, perhaps, with a certain discomfort at dismissing their radicalism so easily - led Hill to discuss levelling in quite peculiar ways. Hill was always keener on "Levellers" than on Lilburne, Overton, Walwyn, Wildman, or even the Agreements of the People or the great petitions which we call Leveller creations. Indeed, Hill's enthusiasm for "Levellers" spilled over into all sorts of discussions and essays, where he recorded with great enthusiasm the "Levellers" who cropped up in a wide variety of contexts. Thus Harrington is cited on the threat from the poor, seen as 'Robbers or Levellers' (Puritanism 276). The ascetic “mad hatter” Roger Crab imagined the cold reception John the Baptist would get if he "should come forth again, and call himself Leveller"; Gerrard Winstanley called Jesus Christ "the head Leveller" (Puritanism 287). Needless to say, the property implications of the term were what made it applicable in such broad ways by contemporaries, and also what made it such an effective derogatory nickname for the movement we now identify as the Levellers. Hill's instinctive enthusiasm for the term, though, especially when combined with his other concerns and commitments, leaves our Levellers in an odd position in Hill's work. Time and again, mention of the Levellers slides into a discussion of Winstanley and the Diggers, focusing relatively briefly on the Levellers on the way. The World Turned Upside Down has a chapter promisingly entitled "Levellers and True Levellers"; but rather than examining the constitutional Levellers in their own right, it skips over them, alternately dissolving them into and putting them in counterpoint with their more radical brethren and successors throughout the chapter, right from a first section entitled "St George's Hill".

The Diggers provided a fulfilment of the Levellers' promise in multiple ways for Hill. Even in the history of our engagement with the seventeenth century, the Levellers must give 
way to the Diggers: "The Levellers were better understood as political democracy established itself in late nineteenth- and early twentieth-century England; the Diggers have something to say to twentieth-century socialists" (World 15). That of course was because the Diggers in their own time had unfolded the logic of the Levellers' thought and pushed it to its natural conclusions: the logic of the Levellers' ideas had slipped away from them and we should follow the ideas to their fuller realization in the thought and practice of the Diggers. Even the Levellers themselves were variable in the extent to which they had pursued the logic of their own ideas, and some of them could be credited with having progressed further towards the economic and social implications of levelling: Hill was sympathetic to the Soviet historian M.A. Barg's notion that two wings of the Leveller movement, with differing tendencies, could be discerned (World 114). For his own part, Hill urged us not to "confine our attention to the organized movement and its leaders" but to "think of something much vaster if more inchoate" (World 64). The significance of this broader movement was that it "went a good deal further than the constitutionalist leaders" in its questioning of property relations - an assertion derived by a dubious back-conjecture from the contemporary accusations and denials of the Levellers' communism. The Levellers, indeed, seemed to have invited this accusation precisely by committing themselves to ideas whose logic led in that direction:

[Ireton] got them ["the Leveller spokesmen" at the Putney debates] into considerable difficulties by stressing the "natural right" basis of their arguments about the franchise: Gerrard Winstanley was to build his communist theories on natural rights, and they were also used by the authors of Light Shining in Buckinghamshire (World 118).

To make this argument work, Hill has (following the hostile Ireton himself) had to put an enormous amount of spin on the ball of "natural rights", which otherwise might curve in any number of different directions, rather than directly towards communism. Hill's enthusiasm 
for the term "Leveller" naturalises the slippage from "Levellers" to the self-proclaimed "True Levellers", the Diggers. In The World Turned Upside Down, Hill insisted again and again on the ways in which contemporaries blurred Levellers and Diggers, deliberately running the two together or using the term "Leveller" in broader contexts than we would. The armyradical newsbook The Moderate was one of Hill's sources here, and it does indeed show us a radical spectrum in which a range of constitutional, social and economic ideas were played out, and material from different (in our view) radical groups run together: Leveller documents, one Digger tract, Jubbes's version of an Agreement of the People and other outcroppings of army radicalism all make their appearances here. It was not, however, "the Leveller newspaper" (as Hill and others have called it) in any meaningful sense, and it does not show us a directional movement from constitutionalist Leveller leaders, desperately trying to put the brakes on the implications of their ideas, towards a groundswell of popular communism (World 120). It seems part of Hill's sustained atttempt to make a penumbra of other radicals seize the title from the constitutionalist Levellers themselves.

My second case-study in Hill's treatment of the tamer brands of civil war radicalism is his sometimes glancing treatment of the Harringtonians, who have occupied such a significant place in the burgeoning study of classical republicanism ever since J.G.A. Pocock's Machiavellian Moment appeared in 1975. Harrington's role is conceived (in passing) in The World Turned Upside Down on the model of the perhaps extraneous "intellectuals" who are required from time to time to shape and systematize plebeian ideas. Harrington, enormously and self-consciously ambitious in his construction of a perfectlyengineered immortal commonwealth, would surely have been horrified by Hill's breezy claim that in his proposed agrarian law "Harrington was only summing up a tradition" - particularly since Hill is not talking about the classical and Machiavellian tradition which Harrington himself claimed allegiance to (World 115). Two aspects of Harrington's thought naturally 
struck a chord with Hill: the primary role which he gave to landed property, leading to his willingness to introduce an agrarian law to limit any accumulation of property great enough to threaten the "popular" balance of the government he proposed; and his understanding of the great forces at work in historical development (World 361). (Hill's account of Harrington in this regard did evolve: in 1958 he criticized Harrington for being too much of an economic determinist, leaving no room for the agency of mass political action, but by 1984 "Harrington's is no mere determinist theory of history. .... Human prudence is necessary to establish an appropriate new constitution [after the property balance has changed]" (Puritanism 280; Experience 195).) Yet Hill found it hard to warm to Harrington, except (as with the Levellers) by dropping heavy hints about the more properly revolutionary ideas with which Harrington's had some affinity, and the perhaps tenuous links he had with more properly radical people. Harrington's view of the importance of landed property for social structure had something in common with Winstanley's (World 136); but in spite of Hill's consistent assimilation of Harrington to his preferred radicals, and particularly Winstanley, Harrington was not ultimately redeemable. Harrington's role for reason might in theory be appealing, but his conception of it compared unfavourably with Winstanley, "whose reason taught not self-interest but co-operation" (Experience 198). The inherent logic of Harrington's ideas pointed forwards, and Hill seized on a rare sign of radical ideas being transmitted in writing rather than disappearing into the untraceable "underground" of dissident speech: commenting on a passage in Daniel Defoe's Jure Divino, Hill writes: Harrington was no doubt the main influence on Defoe's thought about property, and there is no evidence that he had read Winstanley. But the passage is considerably more radical in its implications than anything Harrington ever wrote...(World 381-2) Hill evidently found it frustrating that the transmission of these ideas might be drawn from Harrington rather than the more promising thinker of such thoughts, Winstanley. 
Hill tried to connect Harrington personally as well as through ideas to the more activist radicals of the revolution. The section on Harrington in The Experience of Defeatjustified partly by its chronological treatment - begins with the first systematic exposition of Harringtonian thought in the 1654 Copy of a Letter signed by one R.G. This offered Hill the opportunity to move onto ground where he was more comfortable, by discussing the owner of the initials - Richard Goodgroom, who may or may not have been the sole author of the tract. Here Hill's habitual radical prosopographical mapping came into its own: Goodgroom was an army chaplain who "was a signatory to one of the Digger pamphlets in 1649, became a Fifth Monarchist, was plotting with Colonel Okey in 1656, was recommissioned in 1659 and became chaplain to Robert Overton." Hill was particularly interested in the detail here, because it gives us "an interesting link between Winstanley and Harrington”. Indeed, he speculated that Goodgroom was not the only "intellectual" to have formed a part of the Digger movement, tentatively suggesting other men who may have put in appearances at Digger colonies, even if only as visitors (Experience 192-3). This mapping of links is rather telling: Hill engaged in it when it allowed him to move from classical republicans towards his preferred religious and social radicals, but not in the other direction: although he is indexed as "John Streater", the army man who tartly commented that Christ would have to come before Christmas (of 1653) in order to stand in the way of Cromwell's ambition is vaguely referred to by Hill as "A Major Streater". Hill did not take the opportunity even to identify Streater, let alone to trace Streater's links with Harrington (Puritanism 293).

Ideas, then, could slip away from the people who thought them, drawn along by their own logic and by the logic of historical progress. Thinkers could and did fail to be the best possible thinkers of their own ideas. For Hill, that was often cause for disappointment, and many of his argumentative moves examined above were designed to remedy these failings. But I personally am intrigued rather than disappointed by the slippages between what we 
think we ought to think, what we think we do think, and what we actually think when confronted by particular situations, and find them rather endearing. So it is in sympathy rather than critique that I suggest in closing that Hill himself was not entirely able to line up his sympathies and his thoughts with his professed principles. It is very striking that Hill, who ultimately prized rational and secular modes of thought, was not drawn to the thinkers in this period who best expressed them: the natural rights of the Levellers and the classical republican political reasoning of Harrington. Hill's disappointment in these writers lay partly in their failure to reach the conclusions appropriate to their forward-looking methods and ideas, but I think Hill was also simply more drawn towards dissent and radicalism in their religious than in their more secular forms. Harrington "had a coldly secular attitude towards religion" (Puritanism 277); Hill's response was to assimilate aspects of Harrington's thought to precisely the religious modes which Harrington himself shunned. Thus he conceded that "Harrington's thought is not primarily theological", but lined him up with a variety of millenarian thinkers in interpreting the English civil war as a turning-point in history - even if we might think that it was a significant difference that, in Harrington's case, this was the rise and fall of secular states through natural processes, not the grand sweep of divine history (Experience 193). As Hill himself put it a few pages later, “Harrington's version of English history is a secularized providentialism.” Again Hill sought "parallels, analogies, between Harrington's scheme and radical theological theories" in the idea that in some sense Harrington's account of the natural death of the old regime through a change in the property balance was an analogue of the notion that the sins of the old ruling class had brought it down. In this case they were economic sins - the landowners had failed to improve their land and preserve their economic status - but perhaps that is hardly surprising in Hill (Experience 199). In another comment on the religious and secular matrices of political thought, Hill described the parliamentarian propagandist Henry Parker as "a cool secularist"; he 
characteristically proceeded to warm him up a bit by pointing to Parker's attraction to Calvinist resistance theory as a religious element in his thought (Intellectual Origins 286). Hill seems instinctively to have preferred hot protestants to cool secularists, as long as they were heterodox enough. Even when he valiantly attempted to write an intellectual history of the origins of the civil war which focused on strands of thought other than the potentially revolutionary implications of puritan protestantism, he confessed in his conclusion that "Although I left Puritanism out of my analysis of the intellectual origins of the English Revolution, a discussion of science, history, law, repeatedly brought us back to it" (Intellectual Origins 300).

All this is surprising, given that Hill was sometimes tempted towards reductionist accounts of the functions religion performed for its thinkers, asserting, for example, that "[a]11 thought about economics and politics at this time took religious forms" (Milton 13). Of course personal experience hangs in the background: Hill's own nonconformist family upbringing surely gave these religious milieux part of their familiarity and attractiveness. It may, too, have influenced Hill's attraction to just those kinds of radical ideas which grew in religious contexts and were expressed in religious language. Hill's vision of the world turned upside down was, in one sense, about the working out of ideas in a predetermined direction, towards material equality and community, political democracy, and the rejection of a state church. But in another sense it is a glorious vision of diversity, confusion and profusion; of people following their consciences no matter how few fellow travellers they might find for their own particular beliefs at any particular moment. As with so much in Hill's work, we should be grateful that he could not resist the depth, richness and complexity of the world of religious thought that he explored. 


\section{Works Cited}

Hill, Christopher. The Century of Revolution, 1603-1714. $2^{\text {nd }}$ ed. London: Routledge, 1980; first published 1961. Print.

---, The Experience of Defeat. London: Faber \& Faber, 1984. Print.

---, "From Lollards to Levellers.", Rebels and Their Causes: Essays in Honour of A.L.

Morton. Ed. Maurice Cornforth. London: Lawrence and Wishart, 1978. 49-67. Print.

---, Intellectual Origins of the English Revolution. Oxford: Clarendon Press, 1965. Print.

---, Milton and the English Revolution. London: Faber \& Faber, 1977. Print.

---, Puritanism and Revolution. London: Secker and Warburg, 1995; first published 1958.

Print.

---, The World Turned Upside Down. London: Penguin, 1975; first published 1972. Print.

Kaye, Harvey. The British Marxist Historians. Cambridge: Polity Press, 1984. Print.

MacLachlan, Alastair. The Rise and Fall of Revolutionary England. Basingstoke: Macmillan, 1996. Print.

Macpherson, C. B. The Political Theory of Possessive Individualism. Hobbes to Locke.

Oxford: Clarendon Press, 1962. Print. 